\title{
molecules
}

ISSN 1420-3049

www.mdpi.com/journal/molecules

Article

\section{An Efficient Approach to the Synthesis of Highly Congested 9,10-Dihydrophenanthrene-2,4-dicarbonitriles and Their Biological Evaluation as Antimicrobial Agents}

\author{
Hassan M. Faidallah ${ }^{1{ }^{*}}$, Khalid M. A. Al-Shaikh ${ }^{1}$, Tariq R. Sobahi ${ }^{1}$, Khalid A. Khan ${ }^{1}$ and
} Abdullah M. Asiri ${ }^{1,2}$

1 Department of Chemistry, Faculty of Science, King Abdulaziz University, P.O. Box 80203, Jeddah 21589, Saudi Arabia; E-Mails: khalidyat@hotmail.com (K.M.A.A.-S.); drtariq_s@hotmail.com (T.R.S.); kzsakhan@hotmail.com (K.A.K.); aasiri2@gmail.com (A.M.A.)

2 Center of Excellence for Advanced Materials Research, King Abdulaziz University, P.O. Box 80203, Jeddah 21589, Saudi Arabia

* Author to whom correspondence should be addressed; E-Mail: hfaidallahm@hotmail.com; Tel.: +966-567-743-180.

Received: 8 August 2013; in revised form: 20 November 2013 / Accepted: 10 December 2013/ Published: 16 December 2013

\begin{abstract}
An efficient and novel method for the synthesis in moderate to good yield (72\%-84\%) of a series of 3-amino-1-substituted-9,10-dihydrophenanthrene-2,4-dicarbonitriles 1-5 via one-pot multi-component reactions of aldehydes, malononitrile, 1-tetralone and ammonium acetate has been delineated. Cyclocondensation attempts of aminocyanophenanthrene derivatives 1, 2, 4 and 5 with acetic anhydride in the presence of conc. $\mathrm{H}_{2} \mathrm{SO}_{4}$ failed and instead the diacetylamino derivatives 10-13 were obtained. All prepared compounds were structurally elucidated by various spectroscopic methods and X-ray crystallography. $\mathrm{N}, \mathrm{N}$-diacetylamino-derivatives of phenanthrene have shown good antimicrobial activity.
\end{abstract}

Keywords: dihydrophenanthrene; X-ray crystallography; dihydrobenzo[h]quinoline-3carbonitrile; antimicrobial activity

\section{Introduction}

The phenanthrene moiety is a structural component of many natural products and has been linked to important roles in the pharmaceutical and biological realms. It exhibits a broad spectrum of biological 
activities such as antimalarial [1], anticancer [2] antimycotic [3,4] anti-HIV [5] and emetic properties [6]. C9-substituted phenanthrene-based tylophorine derivatives have shown potential antiviral activity against tobacco mosaic virus (TMV) [7]. In addition, 3,7-dihydroxy-2,4,8-trimethoxyphenanthrene is known for its anti-inflammatory properties [8], while the derivative aristolochic acid exhibits tumor-inhibitory potential [9]. The phenanthrene derivatives 3-hydroxy-2,4-dimethoxy-7,8-methylenedioxyphenanthrene and 2,7-dihydroxy-1-methyl-5-vinylphenanthrene isolated from the rhizomes of Tamus communis exhibit cytotoxicity [10,11]. 9,10-Dihydrophenantherenes with pendant carboxyl groups at position-2 are reported as inhibitors of $5 \alpha$-reductase and useful in the treatment of pharmacological disorders associated with elevated levels of dihydrotestosterone [12].

Various methods have been reported for the synthesis of phenanthrenes [13] and dihydrophenanthrenes [14-20] through ring annulation [21], intermolecular [22] and intramolecular [23] cyclization. A majority of the procedures have certain limitations of accessibility of the precursors, require multiple steps, have harsh reaction conditions, are incompatible with the presence of functional groups, have relatively overall low yields, and lack well-defined regiocontrol elements. Phenanthrenes were prepared from disubstituted biphenyls by intramolecular condensation [22], metal-catalyzed rearrangement of alkene-alkynes [24] and cycloisomerization [25] depending on the functionality present in the biphenyl moiety. Palladium-catalyzed cyclization of arynes with alkynes is an alternative route for the synthesis of phenanthrene [24] and 9,10-disubstituted phenanthrene derivatives [26].

The diverse pharmacological activities and limitations of convenient and efficient procedures prompted us to develop a concise, straight forward and economical route to the synthesis of this class of compounds without use of any catalyst.

\section{Results and Discussion}

\subsection{Chemistry}

It has been reported $[27,28]$ that 5,6 -dihydrobenzo[h]quinoline derivatives are prepared by condensation of the corresponding 2-arylidene-1-tetralone with malononitrile in the presence of ammonium acetate or via one-pot multicomponent reactions (MCRs) of aldehydes, malononitrile, 1-tetralone and ammonium acetate. However, we found that one-pot MCRs of aldehydes, malononitrile, 1-tetralone and ammonium acetate yielded the corresponding phenanthrene derivatives instead of the expected 5,6-dihydrobenzo[h]quinolines (Scheme 1). The probable mechanism for the formation of phenanthrene derivatives is shown in Scheme 2. The structures of these phenanthrene derivatives were elucidated by analytical (Table 1) and spectroscopic data (see Experimental). The conclusive proof of the phenanthrene structure over the quinoline one was given by X-ray crystallography (Figure 1). 
Scheme 1. Synthesis of Compounds 1-9.<smiles>O=C1CCCc2ccccc21</smiles>

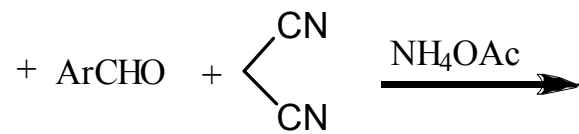<smiles>N#Cc1c(N)c(C#N)c2c(c1Br)CCc1ccccc1-2</smiles>

Ar

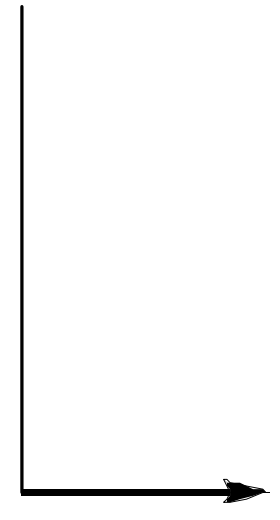<smiles>N#Cc1c(N)c(C#N)c2c(c1[18F])CCc1ccccc1-2</smiles><smiles>N#Cc1c(N)nc2c(c1Br)CCc1ccccc1-2</smiles>
6: $\mathrm{C}_{6} \mathrm{H}_{5}$
7: $4-\mathrm{ClC}_{6} \mathrm{H}_{4}$

8: $\mathrm{C}_{6} \mathrm{H}_{5}$

9: $4-\mathrm{ClC}_{6} \mathrm{H}_{4}$

Scheme 2. A possible mechanism of the formation of 9,10-dihydrophenanthrene-2,4-dicarbonitriles.

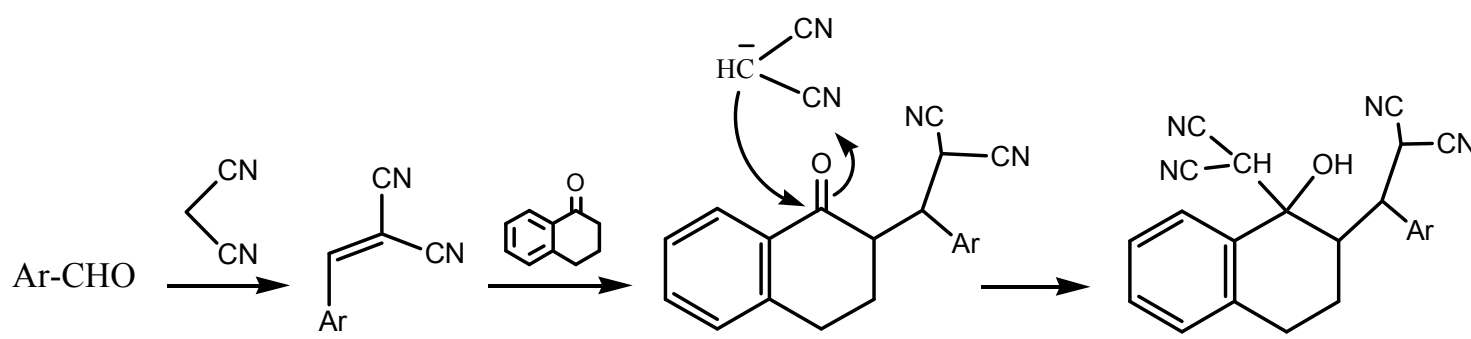

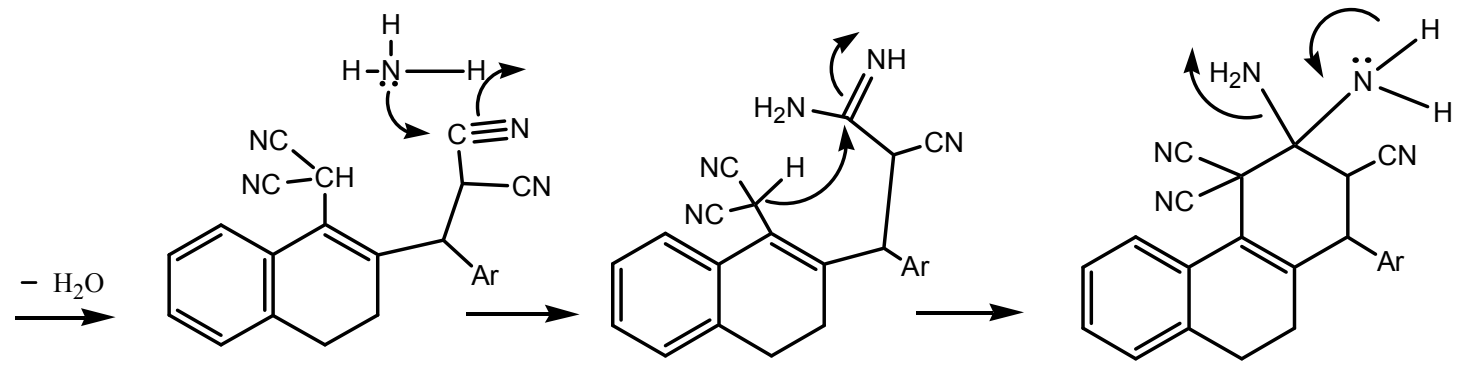

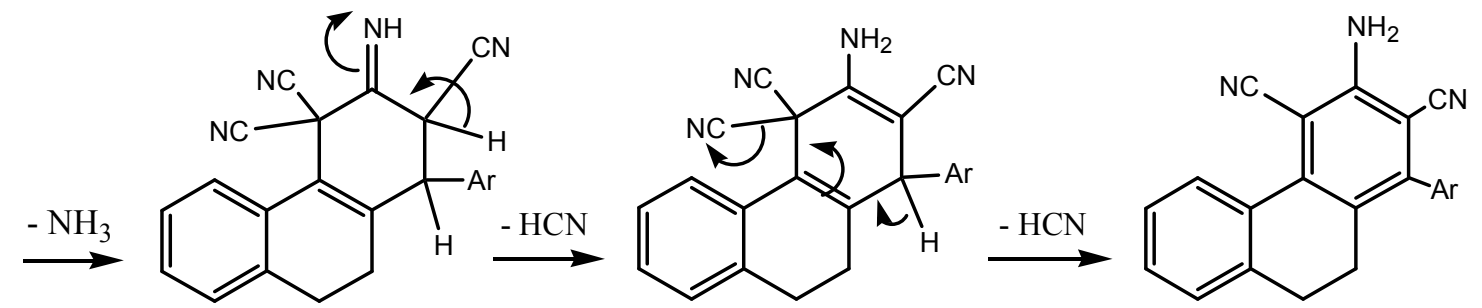


Table 1. Physical and analytical data of compounds 1-13.

\begin{tabular}{|c|c|c|c|c|c|c|c|c|c|c|}
\hline \multirow{2}{*}{ Compd. } & \multirow{2}{*}{$\mathbf{R}$} & \multirow{2}{*}{$\begin{array}{c}\text { Yield } \\
(\%) \\
\end{array}$} & \multirow{2}{*}{$\begin{array}{l}\text { m.p. } \\
\left({ }^{\circ} \mathrm{C}\right) \\
\end{array}$} & \multirow{2}{*}{$\begin{array}{l}\text { Mol. } \\
\text { Formula } \\
\end{array}$} & \multicolumn{3}{|c|}{ Calc. \% } & \multicolumn{3}{|c|}{ Found \% } \\
\hline & & & & & $\mathrm{C}$ & $\mathbf{H}$ & $\mathbf{N}$ & $\mathrm{C}$ & H & $\mathbf{N}$ \\
\hline 1 & $4-\mathrm{BrC}_{6} \mathrm{H}_{4}$ & 76 & $244-246$ & $\mathrm{C}_{22} \mathrm{H}_{14} \mathrm{BrN}_{3}$ & 66.01 & 3.53 & 10.50 & 65.98 & 3.64 & 10.45 \\
\hline 2 & $4-\mathrm{CH}_{3} \mathrm{OC}_{6} \mathrm{H}_{4}$ & 82 & 214-216 & $\mathrm{C}_{23} \mathrm{H}_{17} \mathrm{~N}_{3} \mathrm{O}$ & 78.61 & 4.88 & 11.96 & 78.48 & 4.68 & 11.89 \\
\hline 3 & $3,4-\left(\mathrm{CH}_{3} \mathrm{O}\right)_{2} \mathrm{C}_{6} \mathrm{H}_{3}$ & 78 & $266-268$ & $\mathrm{C}_{24} \mathrm{H}_{19} \mathrm{~N}_{3} \mathrm{O}_{2}$ & 75.57 & 5.02 & 11.02 & 75.62 & 5.16 & 10.87 \\
\hline 4 & $3,4-\left(\mathrm{OCH}_{2} \mathrm{O}\right) \mathrm{C}_{6} \mathrm{H}_{3}$ & 84 & $276-278$ & $\mathrm{C}_{23} \mathrm{H}_{15} \mathrm{~N}_{3} \mathrm{O}_{2}$ & 75.60 & 4.14 & 11.50 & 75.52 & 4.20 & 11.42 \\
\hline 5 & 2-Thienyl & 72 & $220-222$ & $\mathrm{C}_{20} \mathrm{H}_{13} \mathrm{~N}_{3} \mathrm{~S}$ & 73.37 & 4.00 & 12.83 & 73.42 & 3.89 & 12.72 \\
\hline 6 & $\mathrm{C}_{6} \mathrm{H}_{5}$ & 32 & $340-343$ & $\mathrm{C}_{22} \mathrm{H}_{15} \mathrm{~N}_{3}$ & 82.22 & 4.70 & 13.08 & 82.34 & 4.65 & 13.12 \\
\hline 7 & $4-\mathrm{ClC}_{6} \mathrm{H}_{4}$ & 49 & $238-240$ & $\mathrm{C}_{22} \mathrm{H}_{14} \mathrm{Cl} \mathrm{N}_{3}$ & 74.26 & 3.97 & 11.81 & 74.41 & 4.02 & 11.68 \\
\hline 8 & $\mathrm{C}_{6} \mathrm{H}_{5}$ & 50 & $290-293$ & $\mathrm{C}_{20} \mathrm{H}_{15} \mathrm{~N}_{3}$ & 80.78 & 5.08 & 14.13 & 80.82 & 5.11 & 14.23 \\
\hline 9 & $4-\mathrm{ClC}_{6} \mathrm{H}_{4}$ & 12 & $222-225$ & $\mathrm{C}_{20} \mathrm{H}_{14} \mathrm{Cl} \mathrm{N}_{3}$ & 72.40 & 4.25 & 12.66 & 72.36 & 4.32 & 12.61 \\
\hline 10 & $4-\mathrm{BrC}_{6} \mathrm{H}_{4}$ & 82 & 275-277 & $\mathrm{C}_{22} \mathrm{H}_{14} \mathrm{BrN}_{3}$ & 66.01 & 3.53 & 10.50 & 66.12 & 3.51 & 10.75 \\
\hline 11 & 4- $\mathrm{CH}_{3} \mathrm{OC}_{6} \mathrm{H}_{4}$ & 80 & $344-346$ & $\mathrm{C}_{27} \mathrm{H}_{21} \mathrm{~N}_{3} \mathrm{O}_{3}$ & 74.47 & 4.86 & 9.65 & 74.61 & 4.68 & 9.55 \\
\hline 12 & $3,4-\left(\mathrm{OCH}_{2} \mathrm{O}\right) \mathrm{C}_{6} \mathrm{H}_{3}$ & 77 & $265-267$ & $\mathrm{C}_{27} \mathrm{H}_{19} \mathrm{~N}_{3} \mathrm{O}_{4}$ & 72.15 & 4.26 & 9.35 & 72.23 & 4.08 & 9.19 \\
\hline 13 & 2-Thienyl & 76 & $355-357$ & $\mathrm{C}_{24} \mathrm{H}_{17} \mathrm{~N}_{3} \mathrm{O}_{2} \mathrm{~S}$ & 70.05 & 4.16 & 10.21 & 70.12 & 4.22 & 10.31 \\
\hline
\end{tabular}

Figure 1. X-ray crystal structures of some dihydrophenanthrenes and dihydrobenzoquinolines.

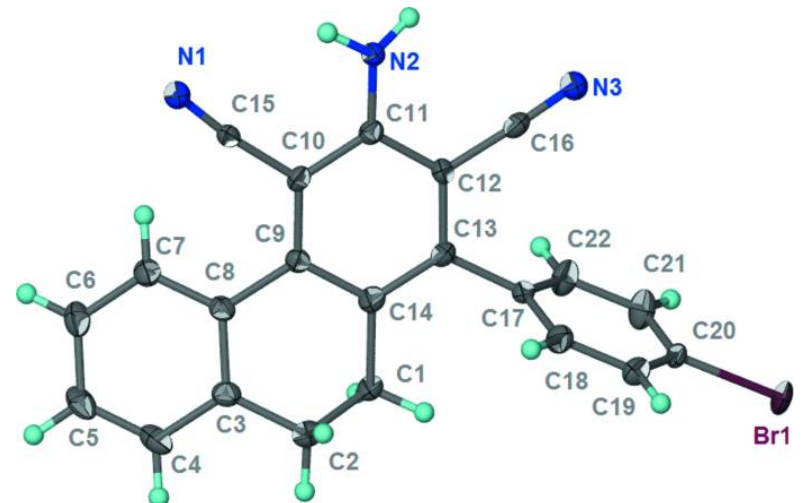

3-Amino-1-(4-bromophenyl)-9,10-dihydrophenanthrene-2,4-dicarbonitrile (1) ${ }^{\text {a }}$

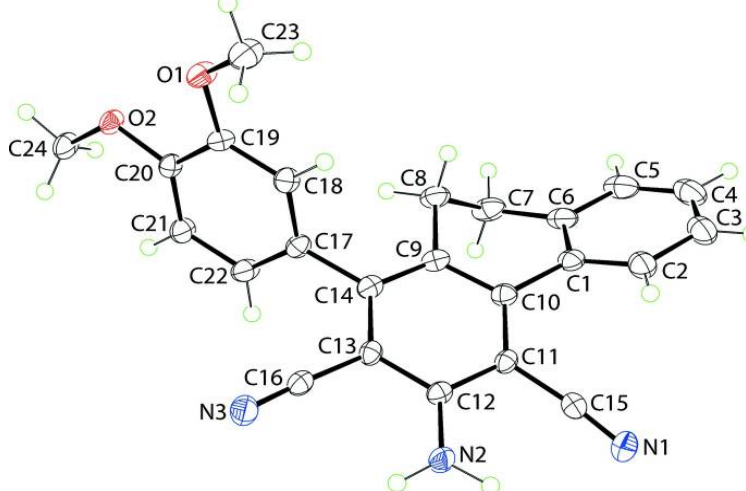

3-Amino-1-(3,4-dimethoxyphenyl)-9,10dihydrophenanthrene-2,4-dicarbonitrile (3) ${ }^{\text {a }}$

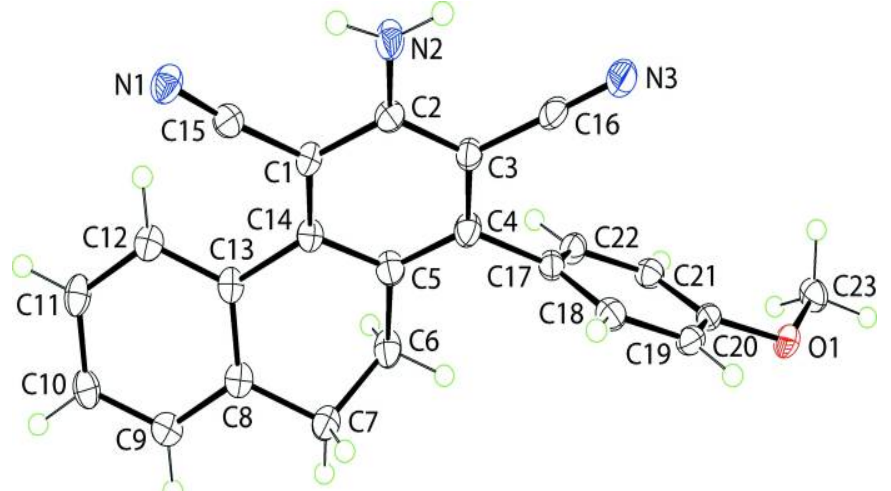

3-Amino-1-(4-methoxyphenyl)-9,10-dihydrophenanthrene2,4-dicarbonitrile (2) ${ }^{\text {a }}$

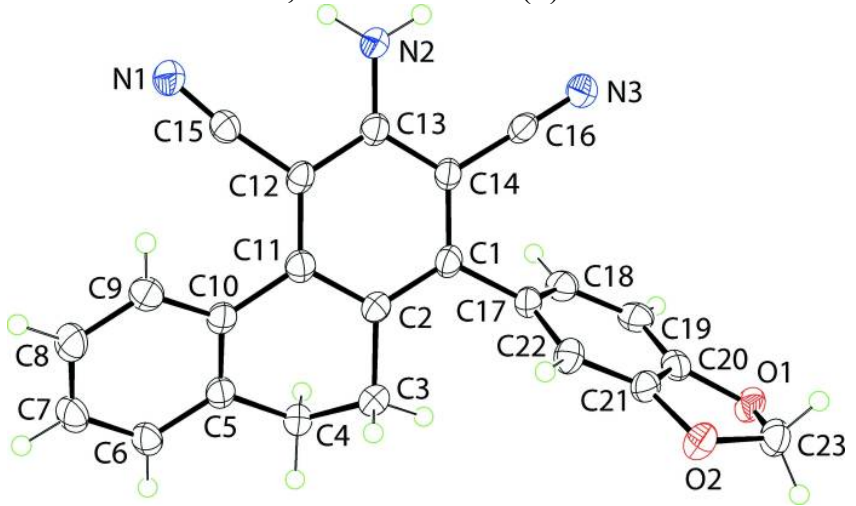

3-Amino-1-(2H-1,3-benzodioxol-5-yl)-9,10dihydrophenanthrene-2,4-dicarbonitrile (4) ${ }^{a}$ 
Figure 1. Cont.

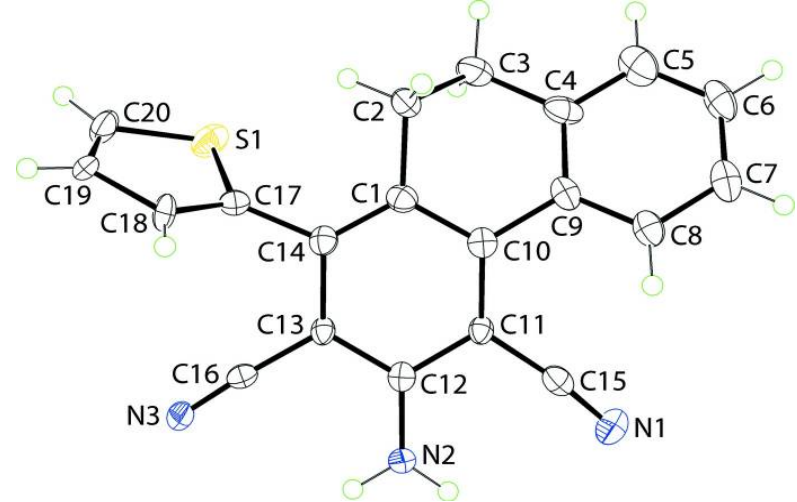

3-Amino-1-(thiophen-2-yl)-9,10-dihydrophenanthrene2,4-dicarbonitrile (5) ${ }^{\text {a }}$

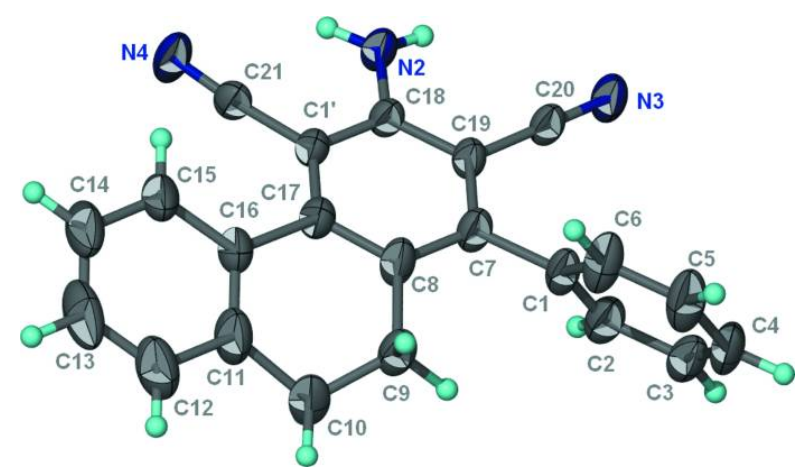

3-Amino-1-phenyl-9,10-dihydro-phenanthrene-2,4dicarbonitrile (7) ${ }^{\mathrm{a}}$

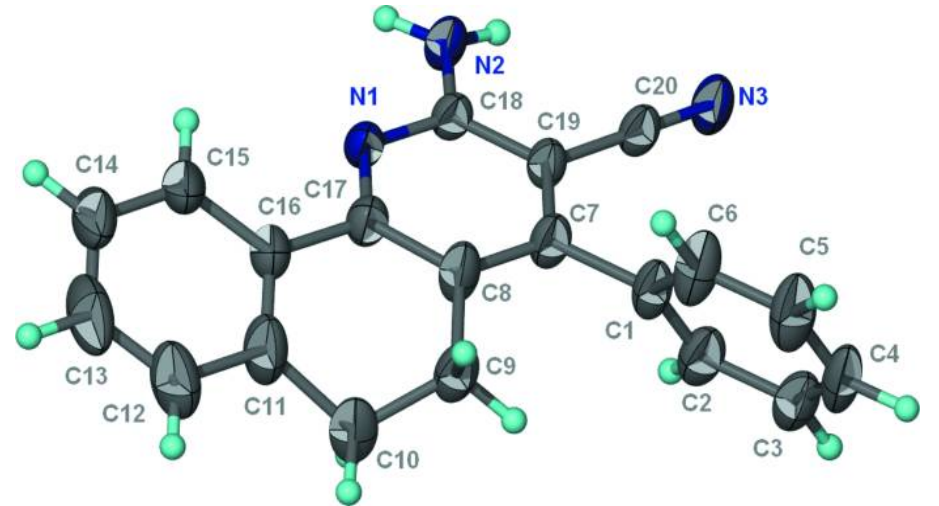

2-Amino-4-phenyl-5,6-dihydro-benzo[h]quinoline-

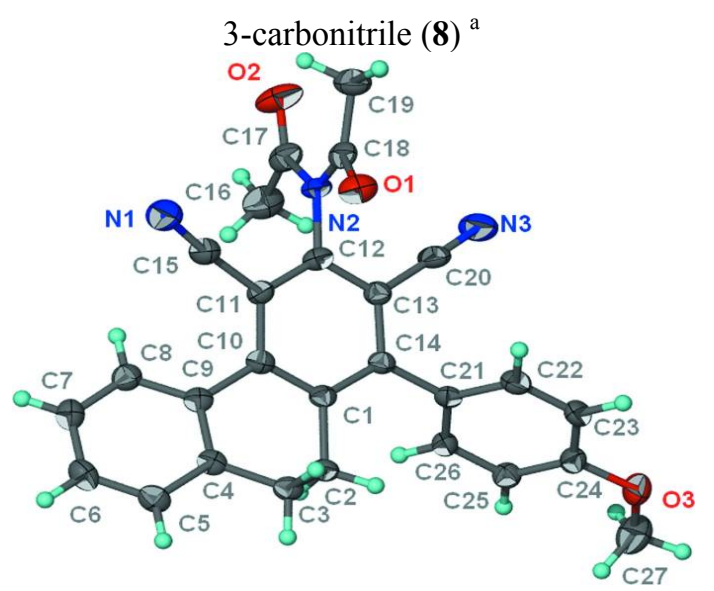

N-Acetyl-N-[2,4-dicyano-1-(4-methoxyphenyl)-9,10dihydrophenanthren-3-yl]acetamide (11) ${ }^{a}$

${ }^{a}$ Source: reprinted from [29-36].

It is worthy to mention here that when the aromatic aldehyde is benzaldehyde, or 4-chlorobenzaldehyde two products were isolated; one is the expected benzoquinoline derivative $\mathbf{8}$ or $\mathbf{9}$ and the other is the unexpected phenanthrene 6 or 7. However, in case of the 4-chlorobenzaldehyde the major product is the phenanthrene derivative (phenanthrene/benzoquinoline 4:1) while with benzaldehyde the benzoquinoline derivative is the major product (benzoquinoline/phenanthrene 5:3).

The formation of the benzoquinoline may be explained according to the following mechanism (Scheme 3). The reaction seemed to be started by first addition of active hydrogen of 1-tetralone to the ethylenic double bond of compound $\mathbf{A}$. Ammonia was added to the nitrile group in $\mathbf{B}$ to give $\mathbf{C}$ which looses a molecule of water to give $\mathbf{D}$, which in turn was converted to the final product by auto-oxidation.

The IR spectra of compounds 1-9 revealed absorption bands at 3,359-3,389 $\mathrm{cm}^{-1}$ characteristic for the $\mathrm{NH}_{2}$ and at 2,318-2,226 $\mathrm{cm}^{-1}$ attributed to the $\mathrm{CN}$ group. Their ${ }^{1} \mathrm{H}-\mathrm{NMR}$ spectra exhibited, besides the aromatic protons at $\delta 7.17-8.02$, two multiplets at $\delta 2.86-2.94$ and 2.80-2.85 ppm corresponding to the benzylic protons $\left(\mathrm{C}^{9}-\mathrm{H}\right.$ and $\mathrm{C}^{10}-\mathrm{H}$ respectively) as well as an exchangeable $\mathrm{NH}_{2}$ at $\delta 6.54-6.67$. The structures were further supported by ${ }^{13} \mathrm{C}$-NMR which showed in addition to the expected number of aromatic carbons, two signals at $\delta 34.2-34.7$ and 26.2-26.8 for the benzyl carbons (C-9 and $\mathrm{C}-10$ respectively). More evidence for the structures of compounds 1-9 arise from their X-ray crystallography [29-35] data which confirm the phenanthrene structure for compounds 1-5 (Figure 1). 
However, when $\mathrm{Ar}=\mathrm{Ph}$ or $4-\mathrm{Cl}-\mathrm{C}_{6} \mathrm{H}_{4}$, the X-ray crystallography confirms that they are a mixture of the benzoquinoline derivatives 6 and 7 and corresponding phenanthrene 8 and 9 .

Scheme 3. A possible mechanism of the formation of benzoquinoline derivatives.

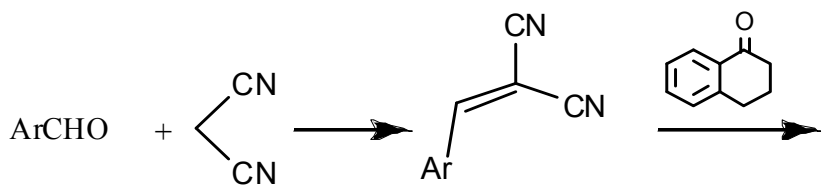

A<smiles>CC(C#N)C(C)C(=O)O</smiles>

B

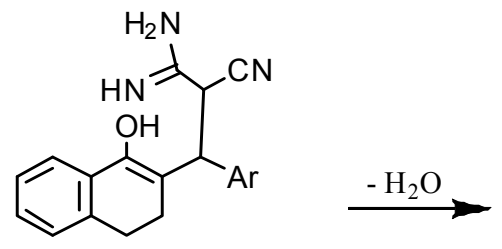

C<smiles>N#CC1C(N)=NC2=C(CCc3ccccc32)C1Br</smiles>

D<smiles>CCC(C)C</smiles>

Attempts were made to prepare 2-methylpyrimidone derivative $\mathbf{E}$ by cyclization of the 3-aminophenanthrene derivatives 1, 2, 4 and 5 with acetic anhydride either in the presence or the absence of conc. $\mathrm{H}_{2} \mathrm{SO}_{4}$ adopting the same procedure reported in the literature [37-40], but these reactions afforded the $N, N$-diacetylaminophenanthrenes 10-13 instead of the expected pyrimidone derivatives (Scheme 4).

Scheme 4. $N, N$-Diacetyl derivatives of dihyrophenenthrene 10-13.<smiles>N#Cc1c(N)c(Cl)c([Al])c2c1CCc1ccccc1-2</smiles><smiles>CCC(C)C=O</smiles><smiles>COc1c([Al])c2c(c(C#N)c1[N+](=O)[O-])-c1ccccc1CC2</smiles>

A $\mathbf{r}$

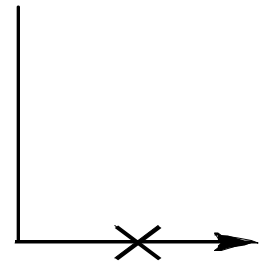<smiles>Cc1nc(C#N)c2c(CCc3ccccc3)c(C)[nH]c(=O)c2c1[Al]</smiles>

1 0: $4-\mathrm{BrC}_{6} \mathrm{H}_{4}$

11: $4-\mathrm{C} \mathrm{H}_{3} \mathrm{OCC}_{6} \mathrm{H}_{4}$

1 2: $3,4-\left(\mathrm{OCH}_{2} \mathrm{O}\right) \mathrm{C}_{6} \mathrm{H}_{3}$

13: 2 -Theiny 1

The IR spectra of compounds 10-13 were characterized by the absence of the $\mathrm{NH}_{2}$ absorption and the presence of two new sharp absorption bands in the $1,666-1,672 \mathrm{~cm}^{-1}$ region due to the new $\mathrm{C}=\mathrm{O}$ groups. Their ${ }^{1} \mathrm{H}$ NMR exhibited, besides aromatic protons at $\delta 7.14-7.48$, two multiplets at $\delta 2.82-2.86$ and 2.84-2.88 ppm corresponding to the $\mathrm{H}-9$ and $\mathrm{H}-10$ respectively, as well as a singlet of six proton intensity at $\delta 2.40-2.44$ for the $2 \mathrm{CH}_{3}$ groups. The structures were further supported by ${ }^{13} \mathrm{C}-\mathrm{NMR}$ data which showed in addition to the expected number of aromatic carbons, two signals at $\delta 34.0-34.5$ and 26.2-26.6 for C-9 and C-10 in addition to the $\mathrm{CH}_{3}$ carbons at $\delta$ 14.7-14.9. More evidence for the structure of compound 11 comes from its X-ray crystallography [36]. 


\subsection{Biological Evaluation}

\subsubsection{In Vitro Antibacterial and Antifungal Activities}

Compounds 1-13 were screened in vitro for their antimicrobial and antifungal activities against Escherichia coli, Staphylococcus aureus, Aspergillus niger and Candida albicans. The zones of inhibition formed for the compounds against bacteria and fungi are summarized in Table 2 . The overall results suggested that compounds containing 3-(N,N-diacetylamino)-substituent exhibited relatively better antimicrobial and antifungal activities when compared with non-acetylated phenanthrene analogs thereby indicating a positive role of diacetyl-substitution in the present series. Compounds $\mathbf{1 0}$ and $\mathbf{1 3}$ were however, significantly active when compared with rest of the series. All test data in Table 2 were of average value from triplicate runs and the test compounds showed reduced antimicrobial activities when compared with their respective standards.

Table 2. Anti-bacterial and anti-fungal data of compounds 1-13.

\begin{tabular}{cccccc}
\hline \multirow{2}{*}{ Compound } & \multicolumn{2}{c}{ Zone of Inhibition in mm } & & \multicolumn{2}{c}{ Zone of Inhibition in mm } \\
\cline { 2 - 3 } \cline { 5 - 6 } & Escherichia coli & Staphylococcus aureus & & Aspergillus niger & Candida albicans \\
\hline $\mathbf{1}$ & 25 & 24 & 18 & 21 \\
$\mathbf{2}$ & 21 & 20 & 15 & 18 \\
$\mathbf{3}$ & 20 & 21 & 14 & 16 \\
$\mathbf{4}$ & 23 & 20 & 13 & 18 \\
$\mathbf{5}$ & 25 & 22 & 16 & 20 \\
$\mathbf{6}$ & 16 & 15 & 12 & 13 \\
$\mathbf{7}$ & 18 & 17 & 14 & 15 \\
$\mathbf{8}$ & 12 & 13 & 10 & 13 \\
$\mathbf{9}$ & 14 & 15 & 12 & 15 \\
$\mathbf{1 0}$ & 30 & 28 & 20 & 22 \\
$\mathbf{1 1}$ & 28 & 26 & 17 & 19 \\
$\mathbf{1 2}$ & 26 & 25 & 19 & 20 \\
$\mathbf{1 3}$ & 29 & 29 & 21 & 22 \\
Ampicillin & 30 & 29 & - & - \\
Clotrimazole & - & - & 33 & 32 \\
\hline
\end{tabular}

\section{Experimental}

\subsection{General Methods}

Melting points were determined on a Gallenkamp melting point apparatus and are uncorrected. The infrared (IR) spectra were recorded on Shimadzu FT-IR 8400S infrared spectrophotometer using the $\mathrm{KBr}$ pellet technique. ${ }^{1} \mathrm{H}$ - and ${ }^{13} \mathrm{C}$-NMR spectra were recorded on a Bruker DPX-400 FT NMR spectrometer using tetramethylsilane as the internal standard and DMSO- $d_{6}$ as a solvent (chemical shifts in $\delta, \mathrm{ppm}$ ). Splitting patterns were designated as follows: $s$ : singlet; $d$ : doublet; $m$ : multiplet; $q$ : quartet. Elemental analyses were performed on a 2400 Perkin Elmer Series 2 analyzer and the found values were within $\pm 0.4 \%$ of the theoretical values. Follow up of the reactions and checking the 
homogeneity of the compounds were made by TLC on silica gel pre-coated aluminum sheets (Type 60 F254, Merck) and the spots were detected by exposure to UV-lamp at $\lambda 254$.

\subsubsection{3-Amino-1-substituted-9,10-dihydrophenanthrene-2,4-dicarbonitriles 1-5}

A one-pot mixture of the appropriate aldehyde $(10 \mathrm{mmol}), 3,4$-dihydro- $2 H$-naphthalene-1-one $(1.46 \mathrm{~g}, 10 \mathrm{mmol})$, malononitrile $(0.66 \mathrm{~g}, 10 \mathrm{mmol})$ and ammonium acetate $(6.2 \mathrm{~g}, 80 \mathrm{mmol})$ in absolute ethanol $(50 \mathrm{~mL})$ was refluxed for $6 \mathrm{~h}$. The reaction mixture was allowed to cool, and the resulting precipitate was filtered, washed with water, dried and recrystallized from DMF. Yields, 72\%-84\%; IR: (cm $\left.{ }^{-1}, \mathrm{KBr}\right): 3357-3361,3420-3428\left(\mathrm{NH}_{2}\right), 2220-2231(\mathrm{CN})$.

3-Amino-1-(4-bromophenyl)-9, 10-dihydrophenanthrene-2,4-dicarbonitrile (1): ${ }^{1} \mathrm{H}-\mathrm{NMR}$ (DMSO- $\left.d_{6}\right) \delta$ ppm: $2.86\left(\mathrm{~m}, 2 \mathrm{H}, \mathrm{C}-9\right.$ protons), $2.80(\mathrm{~m}, 2 \mathrm{H}, \mathrm{C}-10$ protons $), 7.12\left(\mathrm{~s}, 1 \mathrm{H}, \mathrm{NH}_{2}\right), 7.24-7.48(\mathrm{~m}, 9 \mathrm{H}$, Ar-H). ${ }^{13} \mathrm{C}-\mathrm{NMR}$ (DMSO- $d_{6}$ ) $\delta$ ppm: 34.2 (C-9), 26.3 (C-10), $116.6(\mathrm{CN}), 97.5,126.2,126.4,127.3$, $127.5,128.6,129.1,129.5,136.2,136.7,139.0,145.2,152.0(\mathrm{Ar}-\mathrm{C})$.

3-Amino-1-(4-methoxyphenyl)-9, 10-dihydrophenanthrene-2,4-dicarbonitrile (2): ${ }^{1} \mathrm{H}-\mathrm{NMR}$ (DMSO- $d_{6}$ ) $\delta$ ppm: 2.88 (m, 2H, C-9 protons), 2.83 (m, 2H, C-10 protons), $3.74\left(\mathrm{CH}_{3} \mathrm{O}\right), 6.98\left(\mathrm{~s}, 1 \mathrm{H}, \mathrm{NH}_{2}\right)$, 6.85-7.49 (m, 8H, ArH). ${ }^{13} \mathrm{C}-\mathrm{NMR}$ (DMSO- $\left.d_{6}\right) \delta$ ppm: 33.8(C-9), $26.2(\mathrm{C}-10), 56.1\left(\mathrm{CH}_{3} \mathrm{O}\right), 116.5$ (CN), 97.4, 114.4, 126.2, 126.6, 127.5, 128.4, 128.7, 129.4, 136.1, 139.4, 145.2, 151.8, 160.6 (Ar-C).

3-Amino-1-(3,4-dimethoxyphenyl)-9, 10-dihydrophenanthrene-2,4-dicarbonitrile (3): ${ }^{1} \mathrm{H}-\mathrm{NMR}$ (DMSO- $d_{6}$ ) $\delta$ ppm: 2.86 (m, 2H, C-9 protons), 2.82 (m, 2H, C-10 protons), $3.72\left(\mathrm{CH}_{3} \mathrm{O}\right), 3.73\left(\mathrm{CH}_{3} \mathrm{O}\right), 6.87\left(\mathrm{~s},{ }^{1} \mathrm{H}\right.$, $\left.\mathrm{NH}_{2}\right), 6.72-7.50(\mathrm{~m}, 7 \mathrm{H}, \mathrm{Ar}-\mathrm{H}) .{ }^{13} \mathrm{C}-\mathrm{NMR}$ (DMSO- $\left.d_{6}\right) \delta \mathrm{ppm:} 34.1(\mathrm{C}-9), 26.4(\mathrm{C}-10), 56.2\left(\mathrm{CH}_{3} \mathrm{O}\right)$, $56.3\left(\mathrm{CH}_{3} \mathrm{O}\right), 117.0(\mathrm{CN}), 97.3,114.0,115.5,116.3,120.7,126.3,127.4,128.4,129.6,129.7,135.9$, $139.1,145.2,146.4,148.2,151.8$ (Ar-C).

3-Amino-1-(benzo[d] [1,3]dioxol-5-yl)-9,10-dihydrophenanthrene-2,4-dicarbonitrile (4): $\quad{ }^{1} \mathrm{H}-\mathrm{NMR}$ (DMSO- $\left.d_{6}\right) \delta$ ppm: 2.87 (m, 2H, C-9 protons), 2.80 (m, 2H, C-10 protons), 5.91 $\left(\mathrm{CH}_{2}\right), 6.86(\mathrm{~s}, 1 \mathrm{H}$, $\left.\mathrm{NH}_{2}\right), 6.80-7.48(\mathrm{~m}, 7 \mathrm{H}, \mathrm{Ar}-\mathrm{H}) .{ }^{13} \mathrm{C}-\mathrm{NMR}\left(\mathrm{DMSO}-d_{6}\right) \delta \mathrm{ppm}: 34.2(\mathrm{C}-9), 26.5(\mathrm{C}-10), 117.2(\mathrm{CN})$, $91.2\left(\mathrm{CH}_{2}\right), 97.5,114.2,115.6,116.4,120.7,126.2,127.6,128.5,129.4,129.9,136.0,139.1,145.3$, $146.2,148.4,151.9$ (Ar-C).

3-Amino-1-(thiophen-2-yl)-9,10-dihydrophenanthrene-2,4-dicarbonitrile (5): ${ }^{1} \mathrm{H}-\mathrm{NMR}$ (DMSO- $\left.d_{6}\right) \delta$ ppm: 2.89 (m, 2H, C-9 protons), 2.81 (m, 2H, C-10 protons), $6.75\left(\mathrm{~s}, 1 \mathrm{H}, \mathrm{NH}_{2}\right), 6.98-7.47(\mathrm{~m}, 7 \mathrm{H}$, Ar-H). ${ }^{13}$ C-NMR (DMSO- $d_{6}$ ) $\delta$ ppm: 34.3 (C-9), 26.3 (C-10), $116.9(\mathrm{CN}), 97.2,98.6,122.8,125.2$, $126.3,127.4,127.5,128.3,129.1,136.0,139.1,142.4,145.2,151.8$ (Ar-C).

3.1.2. 3-Amino-1-substituted-9,10-dihydrophenanthrene-2,4-dicarbonitriles 6 and 7 and 2-Amino-4- substituted-5,6-dihydrobenzo[h]quinoline-3-carbonitriles 8 and 9

A mixture of the 1-tetralone $(1.46 \mathrm{~g}, 10 \mathrm{mmol})$, the appropriate aldehyde $(10 \mathrm{mmol})$, malononitrile $(0.66 \mathrm{~g}, 10 \mathrm{mmol})$ and ammonium acetate $(6.2 \mathrm{~g}, 80 \mathrm{mmol})$ in absolute ethanol $(50 \mathrm{~mL})$ was refluxed for 3-6 h. The reaction mixture was cooled and the resulting precipitate was filtered, washed 
with water, dried. The obtained solid was then subjected to column chromatography on silica gel (n-hexane/ethyl acetate 9:1) to give two products. IR: $\left(\mathrm{cm}^{-1}, \mathrm{KBr}\right): 3367-3372,3429-3435\left(\mathrm{NH}_{2}\right)$, 2219-2224 (CN).

3-Amino-1-phenyl-9,10-dihydrophenanthrene-2,4-dicarbonitrile (6): ${ }^{1} \mathrm{H}-\mathrm{NMR}$ (DMSO- $\left.d_{6}\right) \delta$ ppm: 2.86 (m, 2H, C-9 protons), 2.80 (m, 2H, C-10 protons), 7.12 (s, 1H, $\left.\mathrm{NH}_{2}\right), 7.24-7.48$ (m, 9H, Ar-H). ${ }^{13} \mathrm{C}-\mathrm{NMR}\left(\mathrm{DMSO}-d_{6}\right) \delta$ ppm: $34.2(\mathrm{C}-9), 26.2(\mathrm{C}-10), 116.6(\mathrm{CN}), 97.5,126.2,126.4,127.3,127.5$, 128.6, 129.1, 129.5, 136.2, 136.7, 139.4, 145.2, 152.0 (Ar-C).

3-Amino-1-(4-chlorophenyl)-9, 10-dihydrophenanthrene-2,4-dicarbonitrile (7): ${ }^{1} \mathrm{H}-\mathrm{NMR}$ (DMSO- $\left.d_{6}\right) \delta$ ppm: 2.84 (m, 2H, C-9 protons), 2.81 (m, 2H, C-10 protons), 7.03 (s, 1H, NH $), 7.16-7.47$ (m, 9H, ArH). ${ }^{13} \mathrm{C}-\mathrm{NMR}\left(\mathrm{DMSO}-d_{6}\right) \delta$ ppm: 33.3 (C-9), 26.9 (C-10), $117.4(\mathrm{CN}), 97.5,126.1,126.4,127.0$, $127.5,128.4,129.3,129.6,136.2,137.2,139.6,145.4,152.4$ (Ar-C).

2-Amino-4-phenyl-5,6-dihydrobenzo[h] quinoline-3-carbonitrile (8): ${ }^{1} \mathrm{H}-\mathrm{NMR}$ (DMSO- $\left.d_{6}\right) \delta$ ppm: 2.56 (m, 2H, C-5 protons), 2.76 (m, 2H, C-6 protons), $6.45\left(\mathrm{~s}, 1 \mathrm{H}, \mathrm{NH}_{2}\right)$ 7.16-7.98 (m, 9H, ArH). ${ }^{13} \mathrm{C}-\mathrm{NMR}\left(\mathrm{DMSO}-d_{6}\right) \delta$ ppm: $25.2(\mathrm{C}-5), 28.5(\mathrm{C}-6), 117.0(\mathrm{CN}), 89.8,125.5,126.3,126.8,127.1$, $128.4,129.0,138.2,138.8,139.2,155.4,160.6,162.6$ (Ar-C).

2-Amino-4-(4-chlorophenyl)-5,6-dihydrobenzo[h] quinoline-3-carbonitrile (9): ${ }^{1} \mathrm{H}-\mathrm{NMR}$ (DMSO- $\left.d_{6}\right) \delta$ ppm: 2.54 (m, 2H, C-5 protons), 2.72 (m, 2H, C-6 protons), $6.39\left(\mathrm{~s}, 1 \mathrm{H}, \mathrm{NH}_{2}\right), 7.17-8.02(\mathrm{~m}, 8 \mathrm{H}$, ArH). ${ }^{13} \mathrm{C}-\mathrm{NMR}$ (DMSO- $\left.d_{6}\right) \delta$ ppm: $25.4(\mathrm{C}-5), 28.3(\mathrm{C}-6), 116.8(\mathrm{CN}), 90.0,125.3,126.1,126.6$, $127.1,128.1,129.2,129.4,134.3,137.8,138.6,139.1,154.4,160.5,162.4$ (Ar-C).

\subsubsection{3-(N,N-Diacetylamino)-1-(4-bromophenyl)-9,10-dihydrophenanthrene-2,4-dicarbonitriles 10-13}

A mixture of the appropriate 3-aminophenanthrene derivative 1, 2, 4 or 5 (10.00 mmol), acetic anhydride $(5 \mathrm{~mL})$ and conc. $\mathrm{H}_{2} \mathrm{SO}_{4}(0.2 \mathrm{~mL})$ was heated in a boiling water bath for $10 \mathrm{~min}$, then cooled, poured on ice-cold water, treated with $20 \% \mathrm{NaOH}$ solution until it reaches an alkaline $\mathrm{pH}$ ( $\mathrm{pH} 11$ ). The resulting solid product was filtered and recrystallized from ethanol. Yields, $76 \%-82 \%$; IR: $\left(\mathrm{cm}^{-1}, \mathrm{KBr}\right)$ : 2220-2228 (CN), 1692-1705 (C=O).

$N$-acetyl-N-(1-(4-bromophenyl)-2,4-dicyano-9,10-dihydrophenanthren-3-yl)acetamide (10): ${ }^{1} \mathrm{H}-\mathrm{NMR}$ (DMSO- $\left.d_{6}\right) \delta$ ppm: $2.40\left(\mathrm{~s}, 6 \mathrm{H}, 2 \mathrm{CH}_{3}\right), 2.88(\mathrm{~m}, 2 \mathrm{H}, \mathrm{C}-9$ protons), $2.84(\mathrm{~m}, 2 \mathrm{H}, \mathrm{C}-10$ protons), 7.17-7.46 (m, 9H, Ar-H). ${ }^{13} \mathrm{C}-\mathrm{NMR}$ (DMSO- $\left.d_{6}\right) \delta$ ppm: 34.2 (C-9), $26.4(\mathrm{C}-10), 116.8(\mathrm{CN}), 97.4$, $126.3,126.5,127.3,127.7,128.7,129.2,129.8,136.1,136.7,139.1,144.6,151.8$ (Ar-C).

$\mathrm{N}$-acetyl-N-(2,4-dicyano-1-(4-methoxyphenyl)-9,10-dihydrophenanthren-3-yl)acetamide

(11):

${ }^{1} \mathrm{H}-\mathrm{NMR}$ (DMSO- $\left.d_{6}\right) \delta$ ppm: 2.88 (m, 2H, C-9 protons), $2.80\left(\mathrm{~m}, 2 \mathrm{H}, \mathrm{C}-10\right.$ protons), $3.72\left(\mathrm{CH}_{3} \mathrm{O}\right)$, 6.77-7.48 (m, 8H, Ar-H). ${ }^{13} \mathrm{C}-\mathrm{NMR}$ (DMSO- $\left.d_{6}\right) \delta$ ppm: 33.9 (C-9), $26.2(\mathrm{C}-10), 56.0\left(\mathrm{CH}_{3} \mathrm{O}\right), 116.7$ (CN), 97.5, 114.3, 126.2, 126.4, 127.5, 128.5, 128.6, 129.6, 136.1, 139.1, 145.1, 151.9, 160.5 (Ar-C).

$N$-acetyl-N-(1-(benzo[d][1,3]dioxol-5-yl)-2,4-dicyano-9,10-dihydrophenanthren-3-yl)acetamide (12): ${ }^{1} \mathrm{H}-\mathrm{NMR}$ (DMSO- $\left.d_{6}\right) \delta$ ppm: 2.87 (m, 2H, C-9 protons), 2.82 (m, 2H, C-10 protons), $5.90\left(\mathrm{CH}_{2}\right)$, 
6.82-7.48 (m, 7H, Ar-H). ${ }^{13} \mathrm{C}-\mathrm{NMR}$ (DMSO- $\left.d_{6}\right) \delta$ ppm: 34.1 (C-9), 26.3 (C-10), $116.9(\mathrm{CN}), 91.2$ $\left(\mathrm{CH}_{2}\right), 97.4,114.3,115.5,116.4,120.5,126.1,127.5,128.4,129.3,129.9,136.0,139.1,145.4,146.1$, 148.3, 151.7 (Ar-C).

$N$-acetyl-N-(2,4-dicyano-1-(thiophen-2-yl)-9,10-dihydrophenanthren-3-yl)acetamide (13): ${ }^{1} \mathrm{H}-\mathrm{NMR}$ (DMSO- $\left.d_{6}\right) \delta$ ppm: 2.89 (m, 2H, C-9 protons), 2.82 (m, 2H, C-10 protons), 6.88-7.46 (m, 7H, Ar-H). ${ }^{13} \mathrm{C}-\mathrm{NMR}\left(\mathrm{DMSO}-d_{6}\right) \delta$ ppm: $34.2(\mathrm{C}-9), 26.1(\mathrm{C}-10), 116.8(\mathrm{CN}), 97.1,98.5,122.6,125.2,126.2$, $127.4,127.6,128.3,129.2,136.0,139.1,142.2,145.4,152.0(\mathrm{Ar}-\mathrm{C})$.

\subsection{Biological Activity Evaluation}

\subsubsection{Anti-Microbial Activity Procedure}

The preliminary anti-microbial activities of compounds 1-13 were measured in a concentration of $50 \mathrm{mg} / \mathrm{L}$ by disc diffusion method [41,42]. The prepared compounds were tested for their antimicrobial activity against Staphylococcus aureus (ATCC 25923) as Gram positive bacteria, Escherichia coli (ATCC 25922) as Gram negative bacteria, and the antifungal activity was performed using the pathogenic yeast strains Candida albicans and Aspergillus niger. DMSO was used as a solvent and the standard drugs used were ampicillin and griseofulvin. The disc diffusion method was performed using Muller-Hinton agar (Hi-Media) medium. The inhibition zones were measured in $\mathrm{mm}$ at the end of an incubation period of $24 \mathrm{~h}$ at $37{ }^{\circ} \mathrm{C}$ for bacteria and $72 \mathrm{~h}$ at $24{ }^{\circ} \mathrm{C}$ for fungi. The zone of inhibition in $\mathrm{mm}$ is expressed in Table 2. All test data in Table 2 were of average values from triplicate run.

\section{Conclusions}

The present paper describes an efficient and simple method for the synthesis of a series of 3-amino-1-substituted-9,10-dihydrophenanthrene-2,4-dicarbonitriles 1-5 via one-pot multicomponent reactions (MCRs). The structures of these phenanthrene derivatives were elucidated by analytical and spectroscopic data. The conclusive proof of the phenanthrene structure was given by X-ray crystallography. The prepared compounds were screened in vitro for their antimicrobial and antifungal activities. The overall results suggested that compounds containing 3-( $N, N$-diacetylamino)- substituent exhibited relatively better antimicrobial and antifungal activities when compared with non-acetylated phenanthrene analogs, indicating a positive role of diacetyl group in the present series. Compounds $\mathbf{1 0}$ and $\mathbf{1 3}$ were however, significantly active when compared with the rest of the series.

\section{Acknowledgments}

The authors are grateful to the Biology Department, Faculty of Science, University of Alexandria for their help in biological activity evaluation.

\section{Conflicts of Interest}

The authors declare no conflict of interest. 


\section{References}

1. Huffmann, C.W.; Traxler, J.T.; Krbechek, L.; Riter, R.R.; Wagner, R.G. Syntheses of halogenated phenanthrene amino alcohols as antimalarials. J. Med. Chem. 1971, 14, 90-94.

2. Wilson, S.; Ruenitz, P.C. Structural characterization and biological effects of photocyclized products of tamoxifen irradiation. J. Pharm. Sci. 1993, 82, 571-574.

3. Fisch, M.H.; Flick, B.H.; Arditti, J. Structure and antifungal activity of hircinol, loroglossol and orchinol. Phytochemistry 1973, 12, 437-441.

4. Kelly, T.R.; Li, Q.; Bhushan, V. Intramolecular biaryl coupling: Asymmetric synthesis of the chiral b-ring diol unit of pradimicinone. Tetrahedron Lett. 1990, 31, 161-164.

5. Hoshino, H.; Seki, J.-I.; Takeuchi, T. New Antifungal Antibiotics, benanomocins A and B inhibit infection of T-cell with human immunodeficiency virus (HIV) and syncytium formation by HIV. J. Antibiot. 1989, 42, 344-346.

6. Cannon, J.G.; Khonje, P.R.; Long, J.P. Centrally acting emetics. 9. Hofmann and Emde degradation products of nuciferine. J. Med. Chem. 1975, 18, 110-112.

7. Wang, K.; Hu, Y.; Liu, Y.; Mi, N.; Fan, Z.; Liu, Y.; Wang, Q. Design, synthesis, and antiviral evaluation of phenanthrene-based tylophorine derivatives as potential antiviral agents. J. Agric. Food Chem. 2010, 58, 12337-12342.

8. Bordat, P.; Tarroux, R.; Charveron, M.; David, B. Phenanthrene Derivatives, Their Synthesis, Anti-Inflammatory Activity, and Use in Treating Inflammatory Skin Diseases. France Demande WO Patent 2006089881, 2006.

9. Kupchan, S.M.; Wormser, H.C. Tumor inhibitors. X. Photochemical synthesis of phenanthrenes. Synthesis of aristolochic acid and related compounds. J. Org. Chem. 1965, 30, 3792-3800.

10. Kovacs, A.; Forgo, P.; Zupko, I.; Rethy, B.; Falkay, G.; Szabo, P.; Hohmann, J. Phenanthrenes and a dihydrophenanthrene from Tamus communis and their cytotoxic activity. Phytochemistry 2007, 68, 687-691.

11. Dellagreca, M.; Fiorentinob, A.; Isidorib, M.; Lavorgna, M.; Monaco, P.; Previtera, L.; Zarrelli, A. Phenanthrenoids from the wetland Juncus acutus. Phytochemistry 2002, 60, 633-638.

12. Boger, D.L.; Mullican, M.D. Regiospecific total synthesis of juncusol. J. Org. Chem. 1984, 49, 4045-4050.

13. Floyd, A.J.; Dyke, S.F.; Ward, S.E. The synthesis of phenanthrenes. Chem. Rev. 1976, 76, 509-562.

14. Orchin, M.; Woolfolk, E.O. Aromatic cyclodehydrogenation. I. 4-Methylfluorene from 2,2'-Dimethylbiphenyl. J. Am. Chem. Soc. 1945, 67, 122-124.

15. Ram, V.J.; Goel, A. An Expeditious synthesis of 9,10-Dihydrophenanthrene by condensation of 2H-Pyran-2-ones with $\alpha$-Tetralone. J. Chem. Res. (S) 1997, doi:10.1039/A704233G.

16. Erdman, H.; Ronlan, A. Phenol dehydrogenation. Part 11. Intramolecular oxidative coupling of dihydropiceatannol. Acta Chem. Scand. 1969, 23, 249-254.

17. Gilchrist, T.L.; Summersell, R.J. Synthesis of chrysenes and other $a$-fused phenanthrenes by a palladium(0) coupling-Electrocyclic ring closure sequence. J. Chem. Soc. Perkin Trans. 1988, 1, 2595-2601.

18. Rabideau, P.W.; Marcinow, Z. Silicon modified reduction and reductive alkylation-application to the phenanthrene system. Tetrahedron Lett. 1988, 29, 3761-3764. 
19. Bowden, B.F.; Read, R.W.; Ritchie, E.; Taylor, W.C. Synthesis of 9,10-dihydrophenanthrenes including orchinol methyl ether. Aust. J. Chem. 1975, 28, 65-80.

20. Pratap, R.; Ram, V.J. An efficient de novo synthesis of partially reduced phenanthrenes through C-C insertion. J. Org. Chem. 2007, 72, 7402-7405.

21. Catellani, M.; Motti, E.; Baratta, S. A novel palladium-catalyzed synthesis of phenanthrenes from ortho-Substituted Aryl Iodides and Diphenyl- or Alkylphenylacetylenes. Org. Lett. 2001, 3, 3611-3614.

22. Paredes, E.; Biolatto, B.; Kneetmann, M.; Mancini, P. One-step synthesis of 2,9-disubstituted phenanthrenes via Diels-Alder reactions using 1,4-disubstituted naphthalenes as dienophiles. Tetrahedron Lett. 2002, 43, 4601-4603.

23. Almedida, J.F.; Castedo, L.; Fernandez, D.; Neo, A.G.; Romero, V.; Tojo, G. Base-induced photocyclization of 1,2-Diaryl-1-tosylethenes. A mechanistically novel approach to phenanthrenes and phenanthrenoids. Org. Lett. 2003, 5, 4939-4941.

24. Katz, T.J.; Sivavec, T.M. Metal-catalyzed rearrangement of alkene-alkynes and the stereochemistry of metallacyclobutene ring opening. J. Am. Chem. Soc. 1985, 107, 737-738.

25. Furstner, A.; Mamane, V. Flexible synthesis of phenanthrenes by a $\mathrm{PtCl}_{2}$-Catalyzed cycloisomerization reaction. J. Org. Chem. 2002, 67, 6264-6267.

26. Ram, V.J.; Nath, M.; Srivastava, P.; Sharkhel, S.; Maulik, P.R. A facile access to the synthesis of functionalised unsymmetrical biaryls from $2 \mathrm{H}$-pyran-2-ones through carbanion induced $\mathrm{C}-\mathrm{C}$ bond formation. J. Chem. Soc. Perkin Trans. 2000, 1, 3719-3723.

27. Aly, A.S.; El-Ezabawy, S.R.; Abdel-Fattah, A.M. Reactions with $\alpha$-substituted cinnamonitriles: Synthesis of benzo[h]quinolines and naphtho[1,2, b] pyrans. Egypt. J. Pharm. Sci. 1991, 32, 827-834.

28. Al-Mutairi, T.M.; Al-Hazimi, H.M.; El-Baih, F.E.M. One-pot multicomponent synthesis of some 5,6-dihydro-benzo[h]quinoline derivatives. J. Saudi Chem. Soc. 2009, 13, 199-207.

29. Asiri, A.M.; Faidallah, H.M.; Al-Youbi, A.O.; Ng, S.W. 3-Amino-1-(4-bromophenyl)-9,10dihydrophenanthrene-2,4-dicarbonitrile. Acta Crystallogr. Sect. E Struct. Rep. Online 2011, E67, o2745.

30. Asiri, A.M.; Al-Youbi, A.O.; Faidallah, H.M.; Ng, S.W.; Tiekink, E.R.T. 3-Amino-1-(4-methoxyphenyl)-9,10-dihydrophenanthrene-2,4-dicarbonitrile. Acta Crystallogr. Sect. E Struct. Rep. Online 2011, E67, o2449.

31. Asiri, A.M.; Al-Youbi, A.O.; Faidallah, H.M.; Ng, S.W.; Tiekink, E.R.T. 3-Amino-1-(2H-1,3benzodioxol-5-yl)-9,10-dihydrophenanthrene-2,4-dicarbonitrile. Acta Crystallogr. Sect. E Struct. Rep. Online 2011, E67, o2438.

32. Al-Youbi, A.O.; Asiri, A.M.; Faidallah, H.M.; Ng, S.W.; Tiekink, E.R.T. 3-Amino-1-(3,4dimethoxyphenyl)-9,10-dihydrophenanthrene-2,4-dicarbonitrile. Acta Crystallogr. Sect. E Struct. Rep. Online 2012, E68, o1027-o1028.

33. Asiri, A.M.; Faidallah, H.M.; Alamry, K.A.; Ng, S.W.; Tiekink, E.R.T. 3-Amino-1-(3,4-dimethoxyphenyl)-9,10-dihydrophenanthrene-2,4-dicarbonitrile. Acta Crystallogr. Sect. E Struct. Rep. Online 2012, E68, o1118-o1119. 
34. Asiri, A.M.; Al-Youbi, A.O.; Faidallah, H.M.; Ng, S.W. 2-Amino-4-(4-chlorophenyl)-5,6dihydrobenzo[ $h]$ quinoline-3-carbonitrile-3-amino-1-(4-chlorophenyl)-9,10-dihydrophenanthrene2,4-dicarbonitrile (1/4). Acta Crystallogr. Sect. E Struct. Rep. Online 2011, E67, o2874.

35. Asiri, A.M.; Al-Youbi, A.O.; Faidallah, H.M.; Ng, S.W. 2-Amino-4-phenyl-5,6-dihydrobenzo[h]quinoline-3-carbonitrile-3-amino-1-phenyl-9,10-dihydrophenanthrene-2,4-dicarbonitrile (5/3). Acta Crystallogr. Sect. E Struct. Rep. Online 2011, E67, o2872.

36. Asiri, A.M.; Faidallah, H.M.; Al-Thabaiti, S.A.; Ng, S.W.; Tiekink, E.R.T. N-Acetyl-N-[2,4dicyano-1-(4-methoxyphenyl)-9,10-dihydrophenanthren-3-yl]acetamide. Acta Crystallogr. Sect. E Struct. Rep. Online 2012, E68, o1177-o1178.

37. El-Baih, F.E.M. Synthesis of some Naphtho[1,2-b]Pyran, Naphtho[1,2-d]Pyrimidine and Benzo[h]Quinoline derivatives. J. Saudi Chem. Soc. 2004, 8, 279-288.

38. El-Baih, F.E.M.; Al-Rasheed, H.H.; Al-Hazimi, H.M. Synthesis of some pyridine and pyrimidine derivatives via michael-addition. J. Saudi Chem. Soc. 2006, 9, 575-596.

39. Otto, H.H.; Schmelz, H. Reaktionen von arylidentetralonen mit cyanessigsäurederivaten. Monatsh. Chem. 1979, 110, 249-256.

40. Bedair, A.H.; El-Hady, N.A.; Abd El-Latif, M.S.; Fakery, A.H.; El-Agrody, A.M. 4-Hydroxycoumarin in heterocyclic synthesis: Part III. Synthesis of some new pyrano[2,3d]pyrimidine, 2-substituted $[1,2,4]$ triazolo[1,5-c]pyrimidine and pyrimido[1,6- $b][1,2,4]$ triazine derivatives. Il Farmaco 2000, 55, 708-714.

41. Kirkpatrick, W.R.; Turner, T.M.; Fothergill, A.W.; McCarthy, D.I.; Redding, S.W.; Rinaldi, M.G.; Patterson, T.F. Fluconazole disk diffusion susceptibility testing of Candida species. J. Clin. Microbiol. 1998, 36, 3429-3432.

42. Premkumar, T.; Govindarajan, S. Antimicrobial study of pyrazine, pyrazole and imidazole carboxylic acids and their hydrazinium salts. World J. Microbiol. Biotechnol. 2005, 21, 479-480.

Sample Availability: Samples of the compounds 1-13 are available from the authors.

(C) 2013 by the authors; licensee MDPI, Basel, Switzerland. This article is an open access article distributed under the terms and conditions of the Creative Commons Attribution license (http://creativecommons.org/licenses/by/3.0/). 